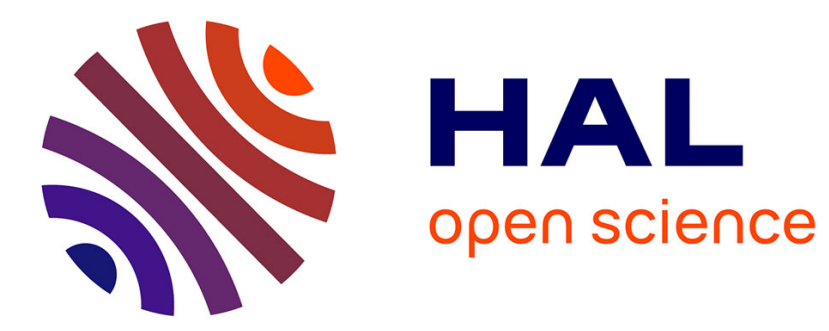

\title{
Territorial Institutions
}

Jean-Claude Thoenig

\section{To cite this version:}

Jean-Claude Thoenig. Territorial Institutions. Rhodes, Binder and Rockman. Territorial Institutions, Oxford University Press, pp.281-302, 2006, The Oxford Handbook of Political Institutions. halshs00139945

\section{HAL Id: halshs-00139945 https://shs.hal.science/halshs-00139945}

Submitted on 4 Apr 2007

HAL is a multi-disciplinary open access archive for the deposit and dissemination of scientific research documents, whether they are published or not. The documents may come from teaching and research institutions in France or abroad, or from public or private research centers.
L'archive ouverte pluridisciplinaire HAL, est destinée au dépôt et à la diffusion de documents scientifiques de niveau recherche, publiés ou non, émanant des établissements d'enseignement et de recherche français ou étrangers, des laboratoires publics ou privés. 
A shorter version has been published in R.A.W. Rhodes, S.A. Binder and B.A. Rockman (eds), The Oxford Handbook of Political Institutions, New York, Oxford University Press, 2006: 281-302.

\section{TERRITORIAL INSTITUTIONS}

Jean-Claude THOENIG

Jean-Claude THOENIG is " directeur de recherche " (emeritus) at Dauphine Recherche en Management (university Paris Dauphine and Centre National de la Recherche Scientifique).

e-mail address= jean-claude.thoenig@dauphine .fr 
Relating territorial administration and political authority is a fundamental problem for public institutions and polities.

The distribution of governmental authority by area and by function had already puzzled the founding fathers of political theory and public administration (Fesler 1949). The question still remains open today: is it possible to define an acceptable level and size of territory for administering policies?

Territories are also specific action and order arenas. Struggles between social movements and political parties, trade-offs between social demands and functional issues, are classic ways to explain political outcomes. Comparatively, the geographic dimensions of conflict and power have been and remain less analyzed by social sciences. Territorial politics as a knowledge domain covers the way groupings are constituted as political and social entities at various spatial levels.

Reflecting a federalist or pluralist perspective, the object of territorial politics is often called intergovernmental relationships. In centralized nation states influenced by Roman law, it is rather defined as the study of center-local relationships.

\section{The territory}

Territory is central to the understanding of political institutions. Common sense defines territory as a geographical factor. Physical space may condition economic activity, social interaction and political jurisdiction. While it seems to be a given, an independent variable provided by nature, geography nevertheless does not determine society, economy and polity. Human activities are not mechanistically induced by climate or topography. Physical features do not constitute the whole meaning of territory as a fundamental feature in politics, policy making and polity (Keating 1998). Territories are also places and arenas.

Social sciences define territory as a dependant variable, for instance as the consequence of human activities, and in any case in a much broader sense than just its physical space or geographical component (Gottmann 1980). Space is an economic, political and social construction. A society is composed of social exchanges and interactions between individuals as well as between classes or kinship systems, that though they are spatially distant from each other, share a common pattern of social embeddedness, and feel close to each other in terms of solidarity and identity. In contemporary polities territory is associated with the spatial limits within which a governmental institution has authority and 
legitimacy, and representation and participation are structured. It frames jurisdictions.

Political institutions seem to play a major role. They constitute territories for public policy and for representation. Reference is usually made to legal documents such as the constitution or to formal polities such as the nation state. The danger of such a narrow approach would be to study territorial politics as a descriptive understanding of legal texts and a narrative of the wills of policy makers who wrote them. It would also restrict the field to the spatial levels that are formalized: the local or municipal, the regional, the state or national, the supranational or international.

Constitutions and states as specific tools of government are quite recent. Anthropologists evidence that polity, economy and society were not separate spheres in most pre-industrial civilizations (Dumont 1977, 1983) History underlines that physical space and national identity did not always matter as much as they do since two hundred years (Braudel 1993). Modern constitutions and states may to some extent rationalize social conventions and continue political patterns that had existed for centuries (Putnam 1993). As a construction, territories are the product of evolution.

A political territory is a social fact characterized by three basic properties:

- distinctiveness and unicity. It is differentiated from other social and geographical spaces by the existence of bordures or barriers. Free and voluntary entrance is not allowed. Membership criteria differentiate insiders from outsiders.

- domination and control. Events and people within that space are submitted to common principles about government and governmental affairs. They define rights and duties, allocate hierarchical authority, design asymmetric relationships, and tend to give the monopoly of coercion to a center.

- socialization and culture. A specific social tissue develops, when not languages, myths and customs. Specific values are diffused and common frameworks instilled. A shared identity allows its members to give some sense to their acts and non-acts as well as to their preferences. A sense of place remains even when boundaries fluctuate.

Territories are made and remade. Those that matter the most in a certain context may not be the ones that are conventionally recognized. From neighborhoods to inter-regions, localities may exist that formally are not governmental or public such as civil society movements and informal functional arenas. Space and its management are defined and redefined not only by lawyers and administrators 
but also by social contest and by changing identities or solidarities among parties.

\section{The center-periphery paradigm}

Territorial politics has been and still is influenced by a paradigm borrowed from modern social sciences: the center-periphery relationships. This conceptual framework is used as a way to approach an empirical object, to generate specific research questions about it, to construct methods and collect evidence, and to infer more general statements.

As a pair of concepts, center and periphery became prominent in the early 1960s. Social sciences define the relationship between a center and a periphery as asymmetric and transitive. Theorists of organization argue that hierarchy of authority and control of the agenda are main control and legitimacy resources of the center in a formal organization (Thoenig 1998b). Sociologists of culture such as Edward Shils suggest that asymmetry or inequality within society derives from the fact that a center has the monopoly of defining what is sacred, with the ultimate and irreducible content in the realm of beliefs, values, and symbols (Shils 1975). The periphery is frequently taken to be in itself awkward, narrow minded, unpolished and unimaginative. To avoid impoverished autonomy, it accepts enriching dependence and defers to the center as providing the locus of excellence, vitality and creativity. Centrality provides cultural salvation. The center also controls action tools such as roles and institutions that embody these cultural frameworks and propagate them.

Edward Shils' theory considers centrality as a metaphor, which has little to do with geography. It also advocates a consensus based social life. Paradoxically his paradigm became a reference for political economists who were more sensitive to spatial dimensions and who argued that underdevelopment (Frank 1967) and world order (Wallerstein 1974) were far from consensual. Dependency theories argue that conflict loaded domination relationships link core or metropolis to satellites or peripheries. The center imposes a principle of order, acts as a dominator and structures a unitary capacity to a periphery that is fragmented, disorganized and not cohesive.

Considered as an analytical framework the centrality perspective stresses the need for a systemic understanding and interpretation. Asymmetries, cultural flows, dependencies are research questions, not postulates. It is up to inquiry to verify how far, in a given empirical context, the center also depends on the periphery, if the relationships between national, regional and local levels really are transitive or linear, in which conditions the role of the center is stable, increasing or losing ground, and more than one center may no exist. 
The center-periphery framework assumes the existence of a two level social system. The fact is that most if not all national states are territorially governed by systems that have three if not more tiers. The status of intermediary layers such as regions, counties or states in federal systems, implies analytical attention.

\section{Contemporary issues}

Territory had been closely associated with the emergence and the triumph of the nation state throughout Europe. But, at the end of the $19^{\text {th }}$ century, it started to be considered as a legacy of traditional society. Its decline was predicted. The reason was that massive urbanization, a new social division of labor and the expansion of economic markets would require more functional approaches (Durkheim 1964). Differentiated localisms would be merged into a unified national system. Territorial roots and identities would be substituted by functional and economic cleavages (Paddison 1983).

Students of political institution scholars no longer gave much attention to a phenomenon considered as belonging to the past. The reason was partly due to a theoretical confusion. The economy became internationally integrated. Distance was shortened in terms of time of transportation. Cultural standardization and mass markets spread around the globe. Functional cleavages in industrial and urbanized societies were fought out mainly at the summit of the political system - nationally or internationally - and in any case independently of the vertical relations between territorial subunits and national governments. Modernization was considered as incompatible with territory.

The situation changed gradually in the 1960s when it was found that territorial issues, far from declining or being marginal, were coming back on the political agenda in many countries. Sub-national levels of government were absorbing a greater share of governmental growth than the center (Sharpe 1988). Political movements emerged around regional identities. Decentralization was claimed as a way to free local economic and cultural initiatives. New social classes and groupings questioned political representation and accountability. Sub-national levels and territorial authorities also provided more effective and less costly solutions to policy issues than bureaucratic welfare states.

Territorial politics had to fight the skepticism of a dominant a-spatial academic paradigm. Real world developments forced social sciences to revisit the topic. Territorial components of political institutions and public administration are back in a globalization context. Modernization requires strong local and regional 
components as well as strong national when not supranational authorities and capabilities. They suggest how complex the relation is between function and territory, between world order and localism. People carry multiple territorial identities: they feel at the same time European, French, Parisian, member of an arrondissement. Problems require the coordination of a growing number of components, national, sub-national and supranational. The state, even in the countries where it is strong and centralized, is unable to manage by itself the various facets of life. How polities provide in a sustainable manner hybrid and volatile configurations becomes a valid research and action question.

The agenda of territorial politics shows remarkable continuity and profound evolution as compared with the mid 1980s (Goldsmith and Newton 1988). While patterns of intergovernmental relations keep changing, the issues societies and economies face and the solutions polities adopt have evolved a lot (Balme et al. 1994). Some issues relate to the evolution of nation states.

Public monies are in shortage. Fiscal crisis in the early 1970s and slower economic development later led some countries to financial quasi-bankruptcies. The exploding costs of the welfare state model were no longer balanced by increasing public revenues. Middle class taxpayers revolted against benefits allocated to lower status groupings. A more global economic and financial order makes it difficult for a single state to have full control of its budgetary policy. The political status of taxation and public finance is still contested.

Rationalization reforms sought to productivity gains and better coordination between various levels. Over the past 40 years territorial institutions and affairs have experienced all kinds of reforms. Some aim at making the administrative apparatus more efficient and more effective. For instance small local jurisdictions are merged. More command and control capacity is given to politically accountable regional leaders to put an end to the autonomy of bureaucratic silos. In extreme cases a wide redistribution of functions and policy domains is undertaken, either by a full nationalization of policy domains or by a strong decentralization of authority, revenues and accountability to lower levels. Other administrative reforms follow more radical alternatives. Functional management are generalized by an agency principle. Quasi-market principles claimed by 'new public management' - style reforms relax the command and control approaches of intergovernmental relationships. They tend to separate the democratic element of government from the managerial aspects of delivering service. Evidence suggests that the impact of such reforms varies between national contexts. In the US reforms tend to increase the autonomy of state and local government vis-à-vis the federal authorities (Peters 2001). In Germany they have not had much impact on such relationships (Wollmann 2001). 
Democratization and participation initiatives are said to strengthen democracy and lower civic apathy. (Gabriel et al. 2000). National government seems out of reach for ordinary citizens. Elections are considered an insufficient voice strategy by inhabitants, and representation an unreliable accountability process to control decision makers. So how do you bring the people back at the subnational level without weakening national control, and how do you co-opt stakeholders and moral cause advocates without lowering the legitimacy of elected bodies?

Regionalisms keep reemerging in many countries (Rokkan and Urwin 1982). Top down regionalism refers to decentralization institutionalized from and by the national level. Bottom up regionalism expresses social mobilization within civil society around ideological references and identity claims (Keating 1998). In most cases they share a common characteristic. They are less violent revolts against an oppressive or colonialist center, aiming at setting up a totally separate nation state, and more claims for institutional autonomy and functional devolution. They express the will to have ethnic or linguistic identities recognized such as in Spain (Moreno 1997). Their recognition may also be used as a top down tool allowing a national government to share the funding of policy domains with sub-national levels considered, or to transfer the administration of specific functions to a level considered as more efficient (Stoltz 2001).

Public problems undergo profound changes. Issues ignore more and more the limits of territorial jurisdictions. They wander around and their treatment may induce externalization effects. The nature of solutions is also changing. This is specially the case when problems cannot be broken down in a set of simple repetitive technical solutions but require horizontal or interdisciplinary approaches adapted to the uniqueness of specific contexts. Solutions become more uncertain while the problem to address more complex. The implications are a major challenge for intergovernmental relationships. A clear and stable division of functions between levels is not any longer possible. At the same time more horizontal coordination is needed. Ad hoc functional flexibility and pragmatic inter-institutional cooperation are required.

Other issues relate to beyond the nation states dynamics. The end of the $20^{\text {th }}$ century and the new millennium are associated with at least three major evolutions.

Supra-national political configurations tend to cover most continents. A spectacular change happens with the emergence of the European Union. Neither a full state nor a mere association of free country members, it provides a fruitful ground for innovative patterns of intergovernmental relationships 
National governments are also challenged by the need to foster economic development in an open economy. Territorial dimensions play more than ever a key role in keeping jobs located in high salary regions while attracting investments in underdeveloped areas.

International relations provide another source for the redistribution of roles and functions with major territorial implications. With the increasing role played by world public institutions, nation states lose the actual control when not the monopoly of regulatory policies in many sectors. In some cases the states become at the same time more territorially minded in some policy domains and much less in others.

These evolutions raise old questions in new terms and new questions in classic terms: the formation of states and about their disintegration, territorial roots of governmental legitimacy, comparative advantages and disadvantages of decentralization and recentralization reforms, constitutional engineering and institutional development, ethnic identities, spatial territories and socioeconomic development

\section{A domain of its own}

Territorial politics is open to differing research traditions and agendas. Streams and domains like local government studies (Chisholm 1989), community studies (Aiken and Mott 1970), policy analysis (Pressman and Wildavsky 1973), urban affairs (Goldsmith 1995), not to mention electoral and party studies (Gibson 1997), international relations and economic sociology, are major information and knowledge sources for the understanding of intergovernmental relationships as such. It is not a coincidence that some of their most visible scholars also actively contribute to the advancement of territorial politics.

Territorial politics has reached the status of a proper domain. It has its own research agenda. An active international community shares common standards and wills. This does not imply uniformity and consensus. Debates are permanent and differentiation exists.

Some forms of national insularities suggest a diversity of emphasis and agendas. Countries such as the US, Britain and France had entered the field quite early in the 1960s and in the 1970s. Britain and France have maintained a persistent stream of publications. In the 1990s the institutional expansion of the EU has offered a new knowledge frontier and has attracted an impressive volume of literature. 
The US had made massive contributions in the 1960s and 1970s. The irony is that American scholars carried out more in-depth field research on European countries than on their own. During the 1970s political scientists like Douglas Ashford and Sidney Tarrow made pioneering contributions on France, the UK, Italy and Sweden (Tarrow 1977; Ashford 1982). In more recent years they have experienced a decline of academic attention to the relationships between federal, state and local levels. Comprehensive textbooks that remain today references had already been published in the 1980s (Anton 1989). In more recent years the US have developed a far greater interest for policy studies dealing mainly with policy performances and who gets what when and how from governments. In parallel they have kept much interest for an established tradition like community power studies.

The international community shares, however, a common standard of scientific excellence. Time is over when distaste for theory, predilection for ideological advocacy and social engineering were acceptable. Eclectic methodology and lack of rigor are discarded, despite the fact that some a-theoretical publications have been quite influential depicting in a learned manner territorial politics in the UK (Bulpitt 1983) or in France (Chevallier 1978). Territorial politics as a scientific domain is borrows massively from disciplines like political science, sociology and economics. The links with prescriptive approaches influenced by law, such as the French 'science administrative', or with mere descriptions of formal institutional settings, as in the case of pre-behavioral American public administration theory, have been cut to a large extent.

In the late 1960s a major project headed by the Centre de Sociologie des Organisations in Paris studied French territorial politics using extensive field observation and identifying in a systematic way the informal links and practices that bind local elected officials and central government bureaucrats and representatives (Thoenig 1975; Grémion 1976). Its apparently normative neutral and empirically rooted perspective and counter- were a source of inspiration for many scholars in Europe and abroad.

In the UK a public funded initiative was launched at the end of the 1970s on the specific topic of center-local government relationships. British political science has become a leading contributor to the advancement of agnostic knowledge in the domain (Rhodes 1981; Goldsmith 1986; Page and Goldsmith 1987; Jones 1988; Sharpe 1989)

France and the UK attracted many pioneering studies before the 1990s. Both countries were facing territorial politics reforms since the 1960s. But their content and the political contexts in which they occurred were very different. In the UK the agenda was loaded with partisan politics and ideological struggles. 
Solutions discussed and adopted also covered a wide spectrum. Debates and initiatives kept going on. In France the issue was much less ideological, more functional and mainly centered around decentralization. Resistance to change was also very strong both at the national and at the local levels. Therefore the major reform decided in 1981 and 1982 under the presidency of François Mitterrand surprised even seasoned observers and politicians (Hayward 1983; Schmidt 1990).

Academic debates are kept alive in a domain because different when not antagonistic research approaches and interpretations are in use. Territorial politics is a rather pluralistic domain theoretically and methodologically. Several classifications of approaches have been suggested (Rhodes 1991; Stoker 1995; Peters and Pierre 2000). They can be subdivided into four main classes: political dynamics, state theories, inter-organizational theory, negotiated governance.

\section{Political dynamics approaches: polities matter}

Modern political science has taken over territorial politics as one of its main sub-disciplines and marginalized traditional public administration during the 1960s in the US and the 1970s in Western Europe. Approaches were borrowed that had the discipline had developed to study other topics such as community power studies or national politics and that were in line with the behavioral revolution launched by the University of Chicago based social scientists (Merriam 1921). Inter-governmental relationships approaches find a major source of inspiration in the pluralist tradition (Dahl 1961). It postulated that a rather specific world called a polity exist with its own processes and rationalities. Institutions are a research problem, not a given. Field research makes a difference. Real practices, and not formal authority, enable an understanding of who matters more and who has less influence. Political dynamics are main causes of a consequence called territorial politics.

Centralization provided the enigma to solve about territorial politics. All major countries on both sides of the Atlantic ocean were experiencing a spectacular concentration of resources, issues to be handled and policy domains covered in the hands of their national authorities, in federal as well as in unitary states. Many writers adopted a way of reasoning that implied a kind of zero sum game. The role of the center increases at the expense of the role of the periphery. The autonomy the localities lose is equal to the autonomy the center wins. In western democracies a general rule is supposed to exist. The reason why central government are able to impose their wills in such an easy way has mainly to do with the fact that local government is politically weak (Page and Goldsmith 1987). 
The interpretation of centralization has fueled intensive debate (King 1993; Stoker 1995). A dual polity approach pushes political scientists to look not only at the national level but to consider also the local levels involved, their interests, cultures and margins of discretion. But it also postulates that the national level acts as a unitary and strategic actor. It assumes that the national state is able to get its decisions implemented. Political science tends to over-estimate the ability of political leaders, either local or national, to set the rules of the game. Alternative approaches such as organization theory give recurrent proof of such fallacies. Is the center a mere set of loosely coupled political fractions? The answer is: it depends, and strong evidence is needed to prove it (Dupuy and Thoenig 1985). The link with old institutionalism is cut when social sciences, having observed how scattered and fragmented the national level polity when not the executive is, adopts words that fit the complexity of the real world (Hayward and Wright 2002).

Mainstream political science favor bottom up approaches. Emphasis is given to local political phenomena. The national level is basically described as a set of background factors such as legalistic principles and budgetary transfers. Historical evolution over more than a century is assumed to explain how the periphery is integrated, the representation models and the national resources allocation structure to localities. Interviews with local elected officials and administrators provide a major data source. Their policy brokerage styles, their administrative activism and partisan commitments are compared. Inferences are made from their experience about political entrepreneurship and political conflict in central-local relationships (Tarrow 1977, Page 1991).

Classic political science rehabilitates the sub-national roots of territorial politics. But some fundamental questions remain open. Does a dense web of national state controlled field agencies - in a country like France, $94 \%$ of state bureaucrats operate locally - make a difference as compared with autonomous agencies acting as agents for a principal, the national executive, or with states in which the center, having very few field agencies of its own, entirely relies on sub-national authorities to implement its territorial policies? Legal and financial data have to be questioned as relevant indicators. For instance, is the percentage of national grants in the revenues of local authorities a reliable indicator of their subordination to national polity and central policy making? Are money and law effective ways for the center to actually call the tune?

Money talks (Wright 1988). The fiscal federalism perspective deals with multilevel of government within the same geographical area, and policy instruments such as intergovernmental grants, fiscal decentralization and revenue sharing (Oates 1999). Normative models are built with respect to the appropriate assignment of tasks and finances, for instance in the case of EU tax 
harmonization and local government finance in the UK (James 2004) or about the equalizing performance of central grants to communes in France (Gilbert and Guengant 2002). Being less focused on functional models, allocating more attention to the strategic behaviors as well as to the precise institutional framework in which they operate, should enable co-operation between social sciences and spatial microeconomics. The synthesis provided by Thomas Anton and his associates about the relationship between federalism and public policy in the US consider money and policy outcomes with the lenses of political science (Anton et al. 1980; Anton 1989).

Political dynamics should test counter-intuitive hypotheses. Increasing centralization does not mechanically imply less autonomy and influence for the localities, quite the reverse. Classic political science approaches tend to assume that political variables explain most of the variance about territorial politics. Are polities really in control? To what extent should one consider political dynamics not as causes but as intended or unintended consequences of sub-national affairs and their government?

$\underline{\text { State theories: global contexts matter }}$

Most state theories share a paradox. They state that macro-level factors determine patterns of central-local relations. Broader political, economic and social contexts give birth to an unending series of crises and changes preventing territorial public affairs to reach a level of stability. Center-local relationships are considered as dependant variables, as social constructs. Independent or exogenous variables explain why and how formal as well as informal links and norms emerge and evolve. Center-local relationships are considered as dependant variables, as social constructs. Independent or exogenous variables explain why and how formal as well as informal links and norms emerge and evolve.

Early social class conflict approaches assumed that local government are mere passive servants of national and international capitalism (Castells and Godard 1974; Dunleavy 1980). Critical scholars argued that territorial politics does not really matter as a relevant knowledge domain and action arena. In the 1980s two less abrupt functional explanations were offered. The dual state thesis argues that the state keeps control of social investment policies at the national level. It leaves the management of social consumption policies in the hands of subnational authorities. Local democracy provides remedies to help the poor fighting the failures of markets while national politics allocates, in a closed corporate manner, support, goods and services to the profitable private sector (Saunders 1982). Social consumption being necessarily subordinate to social investment, local levels are therefore dominated by central levels. Another 
model argued that the domination of the national state stems from the fact that major tensions occur between the center and the localities. Societies are divided and unevenly developed. The local state is caught in a dilemma: it represents local interests to the center but also is in charge of implementing national policies within its jurisdictions (Duncan and Goodwin 1988). A more recent line of reasoning argues that the changing nature of territorial politics at the end of the $20^{\text {th }}$ century is less the consequence of some functional imperatives and more the product of social struggles in unstable international economies and societal orders (Stoker 1990 and 1991; Painter 1991) Post-Fordist mass production and consumption require new regimes to support sustained economic growth. Ruling political elites may still occasionally shape intergovernmental relations according to their wills but they have lost part of their control. Established roles of localities, as set up for a Fordist welfare state, are losing ground. New institutional arrangements are still not stabilized. Local government may not necessarily remain a major player. New management thinking favors principles such as hyper-flexibility, customer-orientation and enterprise culture.

Such a research stream, active in France and in the UK, has been influenced by neo-Marxism and by political economics such as regulationist theory (Aglietta 1979). Urban renewal, housing, employment and fiscal-financial issues provide favorite empirical entry points. Observing local government leads many writers to interpret in a much broader way reforms of the national state. Changes in the socio-economic stratification of the population, formal reform designs and ideological struggles between the left and the right have inspired many writers, especially in the UK (Crouch and Marquand 1989; Rhodes 2000)

\section{$\underline{\text { Inter-organizational analysis: systems matter }}$}

A third research tradition has deep roots in sociology of organizations and the neo-behavioral revolution launched by Herbert Simon and James March (March and Simon 1958). Organizations are considered as pluralist arenas for action. They are structured by and around power games. To satisfy their specific stakes and achieve their respective tasks, actors are dependent from each other. The central concern for this tradition lies in unraveling the extent to which asymmetric exchanges occur and power is distributed. Their actual inner functioning is treated as a central problem for inquiry. Center-local relations are considered as an independent variable, as a cause, and not only as a consequence, of policy-making and polities

Territorial politics borrows massively from this perspective because it allows us to explore the intergovernmental black box: dependence and power games. It assumes that central-local relationships operate like a quasi-organized system, as 
a configuration of inter-organizational relations, and not as a centrifugal set of partitioned worlds. Despite the fact that in most countries no formal pyramidal hierarchy integrates the various levels of government, and that in federal countries states or Länder have a lot of discretionary autonomy, all stakeholders involved in the process of territorial government are linked by some common action ground. The national level acts and non-acts have direct or indirect consequences for the local level, and vice-versa, even when each level does not intervene in exactly the same policy domains.

Michel Crozier and Jean-Claude Thoenig model the central-local relationships in France as a honeycomb structure (Crozier and Thoenig 1976). It links the smallest village to Paris. It views relationships between sub-national elected politicians such as mayors and national state field agents such as prefects as typical and repetitive mutual dependence games. Each of them takes a decisive advantage from getting access and support to a partner belonging to the other institutional side. The reason is that each side controls information, legitimacy, monies, know-how and policies that are crucially needed by the other side. Exchanges of resources are daily practices. The model is structured around a process of cross-regulation that stabilizes the system beyond electoral hazards and partisan diversity. Its members follow informal but strongly established interaction norms. This model explains that the national level would be blind and powerless without having access to the local politicians. Local councils have much more influence on the state than one would expect in a jacobine country like France.

Rod Rhodes suggests a similar model about British territorial politics (1981). It too underscores dependence games between national authorities and local administrators, participants maneuvering for selfish reasons such as achieving their goals, deploying resources to increase their influence while avoiding becoming dependent on other players.

Power is defined as the ability for an actor or a coalition of actors to get from other actors acts and non acts the latter would not deliver without being dependent from the former to succeed in their own task or turf. How some form of compatibility between different logics of action is achieved, by formal coordination or by informal cooperation, how arrangements are worked out between various players active at various levels or the same levels, which kinds of de facto rules and social norms regulate these games between elected legislators and executives, administrative agencies, interest groups, inhabitants and even firms, allow to understand and anticipate why a system operates the way it does, therefore why it handles issues and policies the way it does, 
Inter-organizational analysis relies on case studies. It brings the field work back in. Information collected by observations of daily behaviors and in-depth semistructured interviews plays an important role. It does not rule out that those who have legitimate authority at the top, whether inside specific institutions - for instance the top elected officer such as the mayor in a city - or inside the intergovernmental system - for instance the national cabinet - are also those have real power on issues and policies. But it favors a bottom-up approach and the study of how decisions, whether small and routine based or highly visible and strategic, are made and actually implemented.

Center-local relationships systems are considered as meso social orders,. Their properties do not mechanically and passively reflect the interests of some dominant social class, the wills of the constitutional designers or national folk culture. They also are not mere applications of broader institutional patterns, as institutional theory would predict. Two countries may share a similar federal constitution or may adopt identical new public management guidelines. The chances are high that actually the way they manage territorial affairs shall be very different. In a world of increasing globalization, local variations keep alive across countries, regions and even policy domains. Inter-organizational approaches tend to treat intergovernmental systems as independent variables. Local orders impose appropriate issues, norms and practices to their members that are out of their individual control and awareness.

Territorial systems address specific content issues. Several inter-organizational oriented scholars add two other facets to their analysis: policy networks, and policy analysis.

Power and dependence approaches take into account the impact of territorial inter-organizations systems on and their variation across policy networks. Such networks draw together the organizations that interact within a particular field. Rod Rhodes identifies six types for Britain in which local authorities are involved and that reflect a series of discrete policy interests (1988). They differentiate according to their level of integration. Some are loosely knit. They are basically issue networks regrouping a large number of participants with a limited degree of interdependence such as inner city partnerships (Leach 1985). Others are closely coupled. Their access is restricted. They regroup extremely dependent and homogenous communities belonging to the same regional territory and communities that share common policy and service delivery responsibility (Ranson et al. 1985). Some, called intergovernmental, are moderately integrated such as national bodies representing local government councils (Rhodes 1986). 
Territorial local orders select issues to be part of governmental agendas at various levels and elaborate solutions or policies (Duran and Thoenig 1996). Their legitimacy derives to a large extent from the outcomes they deliver, and not only from law and elections. Roles, interdependence relationships and power structure vary a lot between policy sectors even when the same parties communes, central state agencies, regional councils - are involved. At the same time social norms are shared that allow repetitive games and predictable behaviors to last. His model also comes close to a conclusion made by the Rhodes model. In many cases the standards defined in a rigid way by the centre are not applicable and even applied, unless a lot of flexibility is given to those who locally are implementing national policies. In both countries the center faces a fragmentation constraint. Despite of the existence of the prefect, it lacks coordinating capacity among its many own field agencies and cannot command local authorities. To discover that centralized systems such as France and Great Britain experience similar difficulties imposing a top down approach to centrifugal territories and de facto autonomous actors, even when as in France the State formally controls an impressive web of field agencies, is one of the most valuable contributions of inter-organizational approaches.

\section{Negotiated orders: process matters}

Multi-level governance as a school of thought has emerged in the 1990s. Governance remains a loose concept, ranging from another way to name government to an alternative way to govern (Rhodes 1996). When dealing with intergovernmental relationships, it focuses on the discrepancy between governance and the constitutional map of political life (Rhodes 2000). Governance is a particular form of political game. Its baseline agenda is that territorial relationships should be considered as sets of non-hierarchical linkages (Pierre and Stoker 2000; Peters and Pierre 2001; Bache and Flinders 2004). Negotiated order approaches lead their theorists to criticize for empirical reasons and on ideological grounds the center-periphery paradigm. State-centrism plays the role of a theoretical strawman.

Knowledge evolves because at the same time new approaches offer alternative lenses for interpretation and societal evolutions gain the attention of empirically oriented social scientists. Schools of thought such as new institutionalism, game theory (Scharpf 1988; 1997; 2001) and policy analysis stimulate multi-level governance perspectives. EU integration and the evolving relations between sub-national, national and European levels give birth to numerous publications (Marks et al. 1996; Puchala 1999). Developments propelling multi-level governance also occur within states. Cities in the US (Peters 2001), regions associated with metropolitan areas in EU countries (Le Galès and Harding 1998) have become laboratories for a reinvention of government. The national level 
has less financial incentives to provide to steer sub-national government. Decentralization does not suffice. New inclusive models are developed in many countries such as Scandinavia, Germany, France, the UK, Spain or Japan. The studies underscore three major facets.

National states no longer stand as the 'unrivalled kings of the hill' (Peters and Pierre 2001). Transnational forms and levels of government are massively embedded in sub-national politics. Therefore no more central level exists that has the monopoly of authority. To remain relevant players in the game national levels have more than before it to earn their legitimacy and to build their influence by allocating resources and by acceptable achievements. Another consequence of loosening territorial authority is that institutional relationships do not operate through intermediaries but can take place directly between the local and the transnational authorities. Bypassing regions and states becomes ordinary practice and appropriate behavior when no more formal vertical orders exist.

Parties involved in territorial policy making and politics are not stable. They may come and leave according to issues or spatial territories but also as a result of their own discretionary choice. Who sits around the same table with whom else results from ad hoc opportunistic arrangements. Highly visible programs such as structural funds co-funded by the EU, national states and local authorities have been the major source for regional socio-economic developing in many country members (Smith 1997). Legalistic grant allocation programs by which the center puts incentives on the peripheries lose importance. Local levels in their turn use financial incentives to fund projects that are part of regional interest or belong to state jurisdiction. Cross-funding patterns freely bargained between multiple parties are main vehicles for political bodies like regional councils or communes to finance their own projects. Quasi markets for funding projects are present in strong nation-states (Gilbert and Thoenig 1999). Horizontal pooling and multi-level cooperation also include public-private partnership. Where and when publicness ends or starts is not any longer easy to define.

Constitutionally defined authority or law based procedures matter less than processes of exchanges and bargaining. Order and action stem from open and on-going negotiations. Elected officials question the meaningfulness of principles such as sovereignty and autonomy. Beside governmental authorities public problem definition and solving also involve private firms, lobbies, moral cause groups and inhabitants. A series of policy arenas and wide civil society participation imply that political councils, bureaucracies and parties lose the monopoly of agenda building. All major Western countries follow an identical evolution pattern, from Sweden (Bogason 1998) to Australia (Painter 2001) and 
Canada (Simeon and Cameron 2002). The national center in many cases allocates less money, controls less and decentralizes more. It also uses more constitutive policies to integrate new partners and negotiate their involvement (Duran and Thoenig 1996). Institutionalization of policy arenas and cooptation of issue communities become ordinary tools of government.

Called 'action publique' in French, public governance is defined by some authors as an empirical phenomenon (Thoenig 1998a; Stoker 1998). It refers to the process by which various stakeholders, public and private, deal with mutual dependency, exchange resources, coordinate actions, define some common stake to handle and build goals to reach (Rhodes 1997). For other authors governance means a new theory about politics, policy-making and polities.

Multi-level governance approaches often favor top-down only approaches. The EU framework fascinates analysts by a continuous flow of institutional innovation in many policy domains (Marks et al. 1996). Various models of multi-tiered governance are identified from an action perspective. They are tools that are assumed to generate in a linear way differentiation and transformation across territorial systems (Hooghe 1996). They are by definition able to mobilize territorial interests (Hooghe 1999). Relying on North American and European research, Liesbet Hooghe and Gary Marks claim that the days of central state control are over (Hooghe and Marks 2003). In their opinion, federalism theories have failed reconfiguring authority. They conceptualize two prescriptive models and discuss their respective virtues. A first type conceives of flexible, taskspecific and intersecting jurisdictions. A second type disperses authority to nonintersecting, general-purpose and durable jurisdictions. In their opinion there is exists no alternative to liberal democracy about the way collective decisions should be made. Therefore territorial politics as a domain should focus on jurisdictional design and architecture. For whom collective decisions can and should be made matters more,

Debates are numerous about the actual relevance and the scientific rigor of multi-tiered governance theory. They hardly rely upon evidence about how jurisdictional designs are implemented and do not evaluate actual outcomes they generate (Le Galès 1998). They misconceive institutional path dependencies. Their posture is to assume that macro and meso determinisms can be discarded from an action as well as from an interpretation angle. They even may misunderstand the limits of informal, consensual and inclusive processes of decision-making. In-depth field surveys also suggest that the visible growth of negotiations and governance patterns has not jeopardized democratic legitimacy and the power of politicians. This is suggested by the French case. Over twenty years massive decentralization has occurred. Multi-level governance has become a routine process at all levels. Nevertheless a national political class dominated 
by a lasting and powerful cross-partisan coalition of elected officials cumulating local and national mandates still calls the tune when institutional reforms are considered and decided (Thoenig 2005). Decentralization, modernization and negotiation are acceptable as long as the institutional and legalistic factors that protect their power bases are not jeopardized.

Institutions, but also inter-organizational relationships inside the public sector, are not irrelevant. Therefore multi-level governance theory should escape the "Faustian bargain" model where making a deal leads the parties involved to ignore the darker effects of the deal (Peters and Pierre 2004). Do multigovernance approaches describe spatially ordered relationships or does it refer to networking? The answer is: it depends. Therefore in order to avoid confusion some authors drop the label. Chris Skelcher for instance argues that we should use the concept of polycentrism. He highlights consociationalist solutions (Skelcher 2005). They address institutional solutions for polycentric contexts at two levels: informal norms that pattern behavior in and round them, formal organizational structures and arrangements.

\section{National and comparative contexts}

Defining the main characteristics of territorial politics within countries and classifying national contexts into different types of families are parts of the ambitions many social scientists keep in mind.

Classic political science approaches have initially favored local government based comparisons. Comparing two states ruled by Roman law grounded centralization, Sidney Tarrow finds that in the 1970s partisan politics is the fundamental mechanism of integration between the center and the localities, and that the peripheries are governed in a scattered and bureaucratic way (Tarrow 1977; Tarrow, Katzenstein and Graziano 1979). France is integrated by administrative interactions. Territorial representation matters more than partisan affiliation, and localities are well controlled by seasoned active and management oriented mayors. Studying the Local Government Act of 1972, Douglas Ashford argues that the British central government handles local government structure with a frontal attack suggesting ideological dogmatism and authoritarianism. By contrast France, the ideal type of a Napoleonic centralized state, favors consensual pragmatism and incremental reforms. The reason is that its center is rather weak and cautious, the local political officials having a lot of influence on the wills and the policies of the national state. Britain has a powerful center with a lot of room for functional erratic and inadequate initiatives, local politicians being extraordinarily complacent and vulnerable. (Ashford 1979, 1982 and 1989). 
The interpretative value of soft descriptive approaches has been questioned. More theoretically based patterns should be applied to broader samples of countries. A secondary analysis of monographs on seven unitary European states - Norway, Sweden, Danemark, the UK, France, Italy and Spain - takes into consideration patterns of localism and centralism (Page 1991). Legal and political localism is used as a synthetic denominator. Two types are defined: a Northern European family, a Southern European one. They differ according to two main indicators: legal-constitutional subordination - measured by the relative percentage of total public expenditures of local and national budgets; the proportion of local expenditures financed by grants, and by institutional proxies such as which services in various policy fields localities are mandated or just allowed to deliver -, and political localism - the availability of direct and indirect accesses to the national level. A secondary analysis using identical indicators but adding federal countries suggests a third type, the middle European or Germanic class - Germany, Switzerland, Austria, as well as unitary countries being in the process of quasi-federal devolutions such as Belgium and Spain (Goldsmith 1995). Alternative classifications also distinguish three families; an Anglo type (Britain, North America and Australia), a Southern Europe type (France, Italy, Spain, Belgium, etc), and a Northern Europe (Austria, Scandinavia, Germany, Switzerland, plus Japan) (Hesse and Sharpe 1991). Using US federalism as a reference, Deil Wright shows the existence of several types of intergovernmental phases or models over seven decades (Wright 1988). Comparisons also assess decentralization policies in Latin American states and Spain (Montero 2001).

A central control perspective adds a lot to the discussion of intergovernmental systems. The fact is that during the 1980s and 1990s the ways central governments formally design and informally handle their relationships with subnational levels have experienced major changes in many national states. With a few exceptions, processes of devolution, decentralization, regionalization and merger of local jurisdictions have induced less direct control and operational interference, and more indirect control by regulatory procedures.

A comparative perspective of central control enables to revisit the classifications set up by approaches relying on the autonomy or discretion of local government (Goldsmith 2002). Germanic class countries have experienced the least visible and dramatic changes. The federal level has kept developing forms of cooperation with large urban communes and intermediary tiers that are based on negotiation and bargaining. But the Laender in Germany and the cantons in Switzerland keep playing a very important role in controlling the autonomy of smaller communes. Many Southern countries like France, Spain and Belgium, have significantly reduced central control on sub-national authorities. Intermediary tiers have increased their role vis-à-vis rural and small size 
communes that remain weak players. They control monies and policy domains that matter for them. But they have not been granted the possibility, as in federal countries, to legally redesign the limits, the tasks and the constitution of municipal authorities. In France territorial administration looks more like a market than a hierarchy. The various government levels compete with each other to reinforce their local influence by the power of the purse and by adding new policy domains to their portfolios. A wide variety of inter-institutional patterns of co-operation are at work across the country.

In other unitary countries, no major changes are visible. In Greece and Portugal the center keeps a strong capacity to command and control. In the Netherlands the center remains financially strong and quite active in launching all kinds of experiments. The fact is also that it also has a long established tradition of cogovernance with local governments. The Nordic countries had made major reforms already before the 1980s, as Sweden did, or have regionalized but without going as far as France or Spain. Scandinavia has experienced an increasing fragmentation of local government. Reforms such as user-governed public management, particularized state grants, contracting out of services and neighborhood councils have challenged territorial democracy, increased governance by negotiation and inter-organizational links and not reduced the influence of professionals (Bogason 1996). In the UK Whitehall has decentralized significant functions to Wales, Scotland and Northern Ireland (Keating and Loughlin 2002). Emerging stronger intermediate ties inside national arrangements may limit to some extent the autonomy of localities. At the same time they may provide a tool for further decentralization. While the center has looser control over local authorities, it nevertheless keeps its hands on a number of tools allowing to limit the autonomy of the peripheries.

The case of Western Europe suggests that to classify national states in families requires some prudence. Typologies make national states look more alike than they really are. They give the impression that the evolution of territorial politics is identical across countries. Another lesson is that the growth of transnational arrangements or even economic globalization does not imply a convergence between domestic arrangements. It is not entirely wrong to state that Western Europe is making a transition from local government to local governance (John 2001). But the emergence of the EU as an actor in territorial politics does not make its members states more similar, as reported by a study on sub-national democracy and center-level relations in the 15 member countries (Loughlin 2001). To some extent their institutional fabrics dealing with territorial politics have even become more differentiated. EU announced that it would favor regions as partners of some of its policies. Evidence suggests that in fact regions remain on the whole weak tiers in terms of governmental actors and governance networks (Le Galès and Lequesne 1998). Except in countries like Germany, and 
in a few cases in Spain and Italy, they do not really matter as politically autonomous actors. They rather remain functional frameworks and highly dependent from the national level. Power is sub-divided among numerous levels and networks. A typology of regional government models is applied to 12 major Western Europe states (Keating 1998). Regionalization inside the EU has paradoxically benefited to metropolitan areas and big cities that happen in terms of influence and resources to be the strongest competitors of regional authorities.

The idea that the national states are hollowing out does not make much sense when considering facts (Rhodes 1996). From an intergovernmental relations perspective, regionalization has to be interpreted as an ambivalent process, one of its paradoxes being that transferring finances and policy domains to subnational levels, far from weakening the national center, provides a solution to increase its own power and role in territorial politics (Wright 1998). Transnational levels such as the EU or NAFTA, international or world institutions like the World Bank or the United Nations, have not seized control and command from the central states. Evidence even suggests that in some countries the national legislative and executive branches, and more generally the politicians democratically elected by the people, have not really lost control of the agenda of territorial politics.

\section{Bibliography}

Aglietta. M. (1979) A Theory of Capitalist Regulation. (London: New Left Books)

Aiken, M. and Mott, P.E. (eds.) (1970) The Structure of Community Power. (New York: Random House).

Anton, T.J. (1980) Administered Politics: Elite Political Culture in Sweden. (Boston: Martinus Nijhoff)

Anton. T.J., Crawley. J.P. and Kramer. K.L. (1980) Moving Money. (Cambridge, Mass.: Oelgeschlager, Gunn and Hain)

Anton, T.J. (1989) American Federalism and Public Policy: How the System Works. (Temple: Temple University Press) 
Ashford. D.E. (1979) 'The Limits of Consensus: The Reorganization of British Local Government and The French Contrast'. S. Tarrow, P.J. Katzenstein and L. Graziano (eds). Territorial Politics in Industrial Nations. (New York: Praeger)

Ashford. D.E. (1982) British Dogmatism and French Pragmatism. Central-Local Policymaking in the Welfare State. (London: George Allen and Unwin)

Ashford, D.E. (1989) 'British Dogmatism and French Pragmatism Revisited'. C. Crouch and D. Marquand (eds.) The New Centralism. Britain Out of Step in Europe?. (London: Blackwell).

Bache. I. and Flinders. M. (eds) (2004) Multi-level Governance. (London: Oxford University Press).

Balme. R., Garraud. P., Hoffmann-Martinot. V. and Ritaine. E. (1994) 'Analysing Territorial Policies in Western Europe. The Case of France, Germany, Italy, and Spain'. European Journal of Political Research. An Annual Review, 25: 389-411

Braudel. F. (1993) Civilisation, économie et capitalisme. XVe - XVIIIe siècle. (Paris: Livre de Poche)

Bogason. P. (1996) 'Fragmentation of Local Government in Scandinavia'. European Journal of Political Research. 30, 1: 65-86

Bogason. P. (1998). 'Changes in the Scandinavian Model. From Bureaucratic Command to Interorganisational Negotiation'. Public Administration, 76, 2: $335-54$

Bullpitt. J. (1983) Territory and Power in the United Kingdom: An Interpretation. (Manchester: Manchester University Press).

Castells. M. and Godard. F. (1974) Monopolville. L'entreprise, l'état, l'urbain. (Paris: Mouton)

Chevallier. J. (ed.) (1978) Centre, périphérie, territoire. (Paris: Presses Universitaires de France).

Chisholm, D. (1989) Coordination Without Hierarchy. Informal Structure in Multiorganizational Systems. (Berkeley: University of California Press) 
Crozier. M. and Thoenig. J.C. (1976) 'The Regulation of Complex Organized Systems’. Administrative Science Quarterly, 21: 547-70.

Crouch, C. and Marquand, D. (1989). The New Centralism. Britain Out of Step in Europe? (London: Blackwell)

Dahl. R. (1961) Who Governs? (Yale: Yale University Press)

Dumont. L. (1977) Homo Aequalis. (Paris: Gallimard)

Dumont. L. (1983) Essai sur l'individualisme. Une perspective anthropologique sur l'idéologie moderne. (Paris: Le Seuil)

Duncan. S. and Goodwin. M. (1988) The Local State and Uneven Development. (Cambridge: Polity Press).

Dunleavy. P. (1980) Urban Political Analysis. (London: Macmillan)

Dupuy. F. and Thoenig. J.C. (1985), L'administration en miettes. (Paris: Fayard).

Duran P. and Thoenig J.C. (1996) 'L'Etat et la gestion publique territoriale'. Revue Française de Science Politique, 4: 580-623.

Durkheim. E. (1964) The Division of Labor in Society. (New York: Free Press)

Fesler. J. (1949) Area and Administration. (Alabama: University of Alabama Press)

Frank. A. G. (1967) Capitalism and Underdevelopment in Latin America. (New York: Monthly Review Press)

Gabriel. O.W. Hoffmann-Martinot. V. and Savitch. H. (eds.) (2000) Urban Democracy. (Opladen: Leske und Budrich)

Gibson. E.L. (1997) 'The Populist Road to Market Reforms: Policy and Electoral Coalitions in Mexico and Argentina'. World Politics, 49, 3 :155-83.

Gilbert G. and Thoenig. J.C. (1999) 'Les cofinancements publics : des pratiques aux rationalités'. Revue d'Économie Financière, 51, 1: 45-78

Gilbert. G. and Guengant, A. (2002) 'The Equalizing Performance of Central Government Grants to Local Authorities: The Case of France'. National Tax Association. Proceedings of the $95^{\text {th }}$ Conference. 
Goldsmith. M. (ed.) (1986) New Research in Centre-local Relations. (Aldershot: Gower)

Goldsmith. M. and Newton. K. (1988) 'Centralisation and Decentralisation: Changing Patterns of Intergovernmental Relations in Advanced Western Societies - An Introduction by the Editors' European Journal of Political Research, 16: 359-63.

Goldsmith. M. (1995) 'Autonomy and City Limits'. D. Judge, G. Stoker and H. Wollmann (eds.) Theories of Urban Politics. (London: Sage)

Goldsmith. M. (2002) 'Central Control Over Local Government - a Western European Comparison'. Local Government Studies.28, 3: 91-112.

Gottmann. J. (ed.) (1980) Centre and Periphery: Spatial Variation in Politics. (Beverly Hills: Sage Publications).

Grémion. P. (1976) Le pouvoir périphérique. (Paris: Le Seuil).

Hayward. J.E.S. (1983) Governing France. The One and Indivisible Republic. (London: Weidenfeld and Nicolson).

Hayward. J. and Wright. V. (2002) Governing from the Centre. Core Executive Coordination in France. (Oxford : Oxford University Press)

Hesse. J.J. and Sharpe. L.J. (1991) 'Conclusions'. J.J. Hesse (ed.) Local Governement and Urban Affairs in International Perspective. (Baden-Baden : Nomos)

Hooghe. L. (1996) Cohesion Policy and European Integration. Building Multilevel Governance. (Oxford: Oxford University Press)

Hooghe. L. (1999) 'The Mobilization of Territorial Interests and Multi-level Governance'. R. Balme, D. Chabanet and V. Wright (eds.) (1999) Collective Action in Europe. (Paris : Presses de Sciences Po)

Hooghe, L. and Marks, G. (2003) 'Unraveling the Central State, but How? Types of Multilevel Governance'. American Political Science Review, 97, 2: 223-43.

James. S. (2004) 'Financing Multi-level Government'. Journal of Finance and Management in Public Services. 4, 1: 17-32. 
John. P. (2001) Local Governance in Western Europe. (London : Sage)

Jones. G. (1988) 'The Crisis in British Central-local Relationships'. Governance, 1, 2: 162-84.

Keating. M. (1998) Territorial Restructuring and Political Change. (Cheltenham : Edward Elgar).

Keating. M. (1998). The New Regionalism in Western Europe. Territorial Restructuring and Political Change. (Aldershot: Edward Elgar)

Keating. M. and Louglin. J. (2002) Territorial Policy Communities and Devolution in the United Kingdom. (Badia Fiesolana: European University Institute, Working Paper SPS No 1).

King. D. (1993) 'Government beyond Whitehall'. P. Dunleavy, A. Gramble, I. Holliday and G. Peele (eds.) Between Centre and Locality. (London : Allen and Unwin)

Leach. S. (1985) 'Inner Cities'. In S. Ranson, G.Jones and K.Walsh (eds.) Between Centre and Locality (London: Allen and Unwin).

Le Galès. P. and Lequesne. C. (Eds.). Regions in Europe. (London: Routledge)

Le Galès. P (1998) 'Government and Governance of Regions: Structural Weaknesses and New Mobilisations, ‘. P. Le Galès and C. Lequesne (Eds.). . Regions in Europe. (London: Routledge)

Le Galès. P. and Harding. A. (1998) 'Cities and States in Europe'. West European Politics, 21, 3: 120-45.

Loughlin, J. (ed.) (2001) Subnational Democracy in the European Union. Challenges and Opportunities. (Oxford: Oxford University Press).

March. J.G. and Simon. H.A. (1958) Organizations (New York: Wiley)

Marks. G., Hooge. L. and Blank. K. (1996) 'European Integration from the 80s : State-centric vs Multi-level Governance'. Journal of Common Market Studies, $34: 343-77$.

Merriam. C.E. (1921) 'The Present State of the Study of Politics'. American Political Science Review. 15: 173-85 
Montero. A.P. (2001) 'After Decentralization: Patterns of Intergovernmental Conflict in Argentina, Brazil, Spain, and Mexico. Publius, 31, 4: 43-65

Moreno. L. (1997) 'Federalization and Ethnoterritorial Concurrence in Spain'. Publius, 27, 4:65-85.

Oates. W.E. (1999). 'An Essay on Fiscal Federalism'. Journal of Economic Literature, 37: 1120-49.

Paddison. R. (1983) The Fragmented State. The Political Geography of Power. (Oxford : Rober Blackwell Press)

Page. E. and. Goldsmith. M. (eds.) (1987). Central and Local Government Relations : a Comparative Analysis of West European Unitary States. (Thousand Oaks : Sage).

Page. E. C. (1991). Localism and Centralism in Europe : The Political and Legal Bases of Local Self-Government. (Oxford: Oxford University Press).

Painter. J. (1991) 'Regulation Theory and Local Governement'. Local Government Studies, 17,6:23-43.

Painter. M. (2001) 'Multi-level Governance and the Emergence of Collaborative Federal Institutions in Australia'. Policy and Politics, 29,2: 137-50.

Peters. B.G. and Pierre. J. (2001) 'Developments in Intergovernmental Relations: Towards Multi-level Governance’. Policy and Politics, 29:131-65.

Peters, B.G. (2001) 'Administrative Reform and Political Power in the United States'. Policy and Politics 29, 2: 171-80.

Peters. B.G. and Pierre. J. (2004) 'Multi-level Governance: A Faustian Bargain?'. Bache. I. and Flinders. M. (eds.), Multi-level Governance. (London: Oxford University Press).

Pierre. J. and Stoker. G. (2000) 'Towards Multi-level Governance'. P. Dunleavy, A. Gamble, I. Holliday and G. Peele (eds.) Developments in British Politics. (London: Macmillan)

Pierre. J. and Peters. B.G. (2000) Governance, Politics and the State. (London: Macmillan) 
Pressmann. J. and Wildasky. A. (1973) Implementation. (Berkeley: University of Berkeley Press)

Puchala. D. (1999) 'Institutionalism, Intergovernmentalism and European Integration: A Review Article'. Journal of Common Market Studies, 37: 317-32.

Putnam. R. (1993) Making Democracy Work. Civic Tradition in Modern Italy. (Princeton : Princeton University Press).

Ranson. S, Jones. G. and Walsh. K.(eds.) (1985) Between Centre and Locality (London : Allen and Unwin).

Rhodes. R.A.W. (1981) Control and Power in Central-local Relations. (Aldershot: Gower).

Rhodes. R.A.W. (1986) The National World of Local Governement. (London: Allen and Unwin).

Rhodes. R.A.W. (1988). Beyond Westminster and Whitehall: the Sub-central Governments of Britain. (London: Hyman and Unwin)

Rhodes. R.A.W. (1991) 'Theory and Methods in British Public Administration: The View From Political Science', Political Studies, 39, 3 :

Rhodes. R.A.W. (1996) 'The New Governance: Governing Without Governance'. Political Studies, 44: 652-67.

Rhodes. R.A.W. (1997) Understanding Governance: Policy Networks, Governance, Reflexivity and Accountability. (Buckingham: Open University Press).

Rhodes. R.A.W. (2000). 'Governance and Public Administration'. J. Pierre (ed.). Debating Governance: Authority, Steering and Democracy. (Oxford: Oxford University Press).

Rhodes, R.A.W. (2000). Transforming British Governement. (London: Macmillan)

Rokkan. S. and Urwin. D. W. (eds.) (2002) The Politics of Territorial Identity: Studies in European Regionalism. (London: Sage). 
Saunders. P. (1982) 'Why Study Central-local Relations ?'. Local Government Studies, 8: 55-6.

Scharpf. F. W. (1988) 'The Joint-decision Trap: Lessons from German Federalism and European Integration'. Public Administration, 66, 3: 239-79.

Scharpf. F.W. (1997) 'The Problem-solving Capacity of Multi-level Governance'. Journal of European Public Policy, 4 : 520-38

Scharpf, F. W. (2001). Notes Toward a Theory of Multilevel Governing in Europe. Scandinavian Political Studies. 24, 1: 1-26

Schmidt. V. (1990) Democratizing France: The Political and Administrative History of Decentralization. (Cambridge: Cambridge University Press).

Sharpe. L.J. (1988). 'The Growth and Decentralization of the Modern Democratic State'. European Journal of Political Research, 16 :365-80.

Sharpe. L.J. (1989) 'Fragmentation and Territoriality in the European State System'. International Political Science Review, 10, 3: 223-39.

Shils. E. (1975) Center and Periphery. (Chicago: University of Chicago Press).

Simeon. R. and Cameron. D. (2002) 'Intergovernmental Relations and Democracy. An Oxymoron If There Was Ever One'. H. Bakvis and G. Skogstad (eds.) Canadian Federalism: Performance, Effectiveness and Legitimacy. (Oxford: Oxford University Press).

Skelcher. C. (2005) 'Juridictional Integrity, Polycentrism, and the Design of Democratic Governance'. Governance: An International Journal of Policy, Administration, and Institutions, 18,1: 89-110.

Smith. A. (1997) 'Studying Multi-level Governance : Examples From French Translations if the Structural Funds'. Public Administration. 75 :711-29.

Stoker. G. (1990) 'Regulation Theory, Local Government and the Transition From Fordism'. D. King and J. Pierre (eds.) Challenges to Local Government. (London: Sage)

Stoker. G. (1991) The Politics of Local Government. (London: Macmillan)

Stoker. G. (1995) 'Intergovernmental Relations', Public Administration, 73, 1: $101-22$. 
Stoker. G. (1998) 'Governance as Theory: Five Propositions'. International Social Science Journal, 155/17-28.

Stoltz. K. (2001) 'The political class and regional institution-building: a conceptual framework'. Regional and Federal Studies, 11; 1:80-101.

Tarrow. S. (1977) Between Center and Periphery. Grassroots Politics in Italy and France. (Yale : Yale University Press)

Tarrow, S., Katzenstein, P.J., and Graziano, L. (eds.) (1979). Territorial Politics in Industrial Nations. (New York: Praeger)

Thoenig. J.C. (1975) 'La relation entre le centre et la périphérie en France: une analyse systémique'. Bulletin de l'Institut International d'Administration Publique. 36: 77-123.

Thoenig. J.C. (1998a) 'Politiques publiques et action publique'. Revue Internationale de Politique Comparée, 5, 2: 295-314.

Thoenig. J.C. (1998b) 'How Far is a Sociology of Organizations Still Needed?' Organization Studies, 19: 307-20.

Thoenig. J.C. (2005) 'Territorial Administration and Political Control. Decentralization in France'. Public Administration, 83 :

Wallerstein. I. (1974) The Modern World-System. (New York: Academic Press)

Wollmann. H. (2001) ' Germany's Trajectory of Public Sector Modernisation Continuities and Discontinuities'. Policy and Politics, 29, 2 : 151-71.

Wright. D.S. (1988) Understanding Intergovernmental Relations. (Belmont: Brooks-Cole)

Wright. V. (1998) 'Intergovernmental Relations and Regional Government in Europe : A Sceptical View'. P. Le Galès. and C. Lequesne (Eds.). Regions in Europe. (London: Routledge). 